\title{
WACANA TKI DALAM NOVEL JATISABA KARYA RAMAYDA AKMAL
}

\author{
Muchlas Abror \\ Lembaga Pendidikan Ma'arif NU \\ class.hamka@gmail.com
}

Artikel diterima: 01 Juni 2020

Artikel direvisi: 13 Juli 2020

Artikel disetujui: 26 Agustus 2020

\begin{abstract}
Abstrak
Penelitian ini menggunakan novel Jatisaba karya Ramayda Akmal sebagai objek material. Novel tersebut menceritakan tentang kisah TKI ilegal yang pulang ke kampung halaman di Jatisaba untuk merekrut teman-teman sepermainannya sebagai TKI ilegal. Permasalahan yang ingin di jawab dalam penelitian ini yaitu bagaimana wacana TKI ilegal digambarkan dalam novel tersebut dan bagaimana posisi novel Jatisaba dalam wacana TKI Indonesia serta komentar Ramayda sebagai seorang penulis. Teori yang digunakan dalam penelitian ini yaitu teori wacana Michel Foucault yang lebih spesifik pada eksklusi dan inklusi. Tujuan dilakukannya penelitian ini untuk mengetahui bagaimana wacana TKI dimaknai dalam novel Jatisaba dan untuk mengetahui posisi novel tersebut dalam wacana TKI Indonesia serta komentar yang dilakukan oleh penulis berkaitan dengan wacana TKI Indonesia. Hasil penelitian ini menunjukkan bahwa a) kejahatan kemanusiaan sering menimpa TKI ilegal, b) istilah TKI muncul pertama kali di era kepemimpinan Soeharto mengeksklusi istilah buruh yang digunakan Soekarno yang dianggap memiliki kaitan dengan ideologi komunis, pergerakan buruh, dan revolusi, c) posisi novel Jatisaba berada pada wacana TKI di luar pemerintah, d) Ramayda sebagai penulis menyetujui wacana TKI dari pemerintah, namun menganggap praktik percaloan TKI ilegal tidak mudah diselesaikan.
\end{abstract}

\begin{abstract}
This research uses the novel Jatisaba by Ramayda Akmal as a material object. This novel tells the story of Indonesian migrant workers who break the law returning to their villages in Jatisaba to recruit their friends to become migrant workers. The question that must be answered in this research is how the discourse of Indonesian Migrant Workers is displayed in the novel and how the position of the novel Jatisaba in the discourse of Migrant Workers in Indonesia. The theory that used in this research is discourse theory of Michel Foucault which spesific in eksklusi and inklusi. The purpose of this study is to find out how the discourse of Indonesian migrant workers is interpreted in the novel and to find out the position of the novel in the discourse of Indonesian migrant workers and the comments made by the author relating to the discourse of Indonesian migrant workers. The results of this study indicate that a) crimes against humanity often afflict Indonesian migrants who break the law, b) the term TKI first appeared in the Soeharto era to exclude the labor term used by Sukarno because the term was considered to have links to communist ideology, the labor movement and the revolution, c) Jatisaba's novel position depends on the discourse of migrant workers outside the government, d) Ramayda as a writer, agrees with migrant workers from the government, but considers the practice of brokering illegal migrant workers is not easy to handle.
\end{abstract}

Keywords: discourse, eksklusi, inklusi, TKI, comment

\section{Pendahuluan}

Sebagian besar masyarakat Indonesia masih menganggap bekerja sebagai TKI, sebagai solusi untuk memperbaiki taraf kehidupan. Peningkatan pengiriman TKI dari tahun ke tahun yang disertai dengan perbaikan 
peraturan, dan undang-undang oleh pemerintah membuktikan betapa seriusnya pemerintah untuk memanfaatkan peluang tingginya minat bekerja ke luar negeri tersebut. Pemanfaatan TKI didorong adanya keuntungan yang diperoleh pemerintah dari pemasukan devisa yang besar. Tidak tanggung-tanggung atas sumbangsi devisa tersebut, para TKI diganjar dengan sebutan pahlawan devisa.

Namun benarkah mereka pahlawan, atau mereka hanya dijadikan sebagai objek pemerasan secara legal oleh pemerintah dengan adanya peraturan dan undangundang? Pasalnya meski beberapa TKI mengalami perubahan taraf kehidupan, tidak sedikit pula dari mereka yang mengalami nasib buruk sewaktu bekerja di luar negeri. Bahkan kepulangan mereka ke Tanah Air menyisakan trauma yang berkepanjangan, setelah mendapatkan perlakuan yang tidak manusiawi dari para majikan, seperti penyiksaan, pemerkosaan, pembunuhan, gaji tidak dibayarkan, hingga terjerat kasus humman traficking. Sementara mereka yang mendapatkan keuntungan tidak bisa terlepas dari pekerjaan yang ada di luar negeri.

Potret tersebut akhirnya mendorong beberapa penulis untuk menarasikan keadaan TKI. Beberapa penulis novel seperti Remi Silado, Tasaro, dan Mahfud Ikhwan, menjadikan TKI sebagai bahan dalam novelnya. Tidak ketinggalan Ramayda Akmal juga turut serta menarasikan TKI dalam novel yang berjudul Jatisaba. Jatisaba memiliki cerita yang berbeda dari novelnovel sebelumnya, yanghanya menyoroti TKI dari masalah ekonomi dan keluarga dengan ujung happy ending. Berbeda dengan Jatisaba yang tidak hanya melihat keadaan TKI dari masalah ekonomi dan keluarga, tetapi juga menyangkut masalah-masalah privasi. Tokohtokoh dalam novel digambarkan menjadi TKI ilegal dengan perlakuan yang tidak manusiawi, akan tetapi hal itu tidak menghalangi mereka bekerja ke luar negeri. Selain itu, yang menarik dari Jatisaba adalah tokoh utamanya yang seorang lulusan sarjana tetapi menjadi TKI ilegal. Hal ini menimbulkan tanda tanya mengingat seorang sarjana memiliki pola pikir yang lebih maju ketimbang yang lain.

Gambaran tersebut membuktikan bahwa ada kekuasaan dibaliknya yang memainkan wacana TKI dan memproduksinya terus menerus. Menciptakan keseragaman pengetahuan berkaitan dengan TKI sebagai solusi setelah di dalam negeri, tidak mampu mendapatkan pekerjaan.

Wacana erat kaitannya dengan hasrat dan kekuasaan. Wacana dimaknai sebagai objek sekaligus hasrat dari kekuasaan itu sendiri. Wacana tidak sekadar segala yang menerjemahkan peraturan atau sistem-sistem dominasi, melainkan hal yang menjadi tujuan dan sekaligus cara dari pertarungan itu (Faruk, 2017). Wacana tidak bisa dilepaskan dari adanya counter wacana, dengan demikian wacana merupakan kuasa yang harus direbut dan dipertahankan dengan memproduksinya terus menerus sehingga menjadi landasan berpikir pada zaman tertentu. Seperti anggapan menjadi TKI sebagai solusi meningkatkan taraf kehidupan. Dengan demikian, adanya peraturan dan undangundang yang terus diperbaiki, dapat dikatakan sebagai upaya kekuasaan dalam menjaga keberlangsungan wacana tersebut.

Wacana bukan sesuatu hal yang memiliki bentuk yang sama di setiap zaman, melainkan terus mengalami transformasi sesuai dengan kebutuhan kekuasaan di tiap zamannya. Tujuannya untuk mempertahankan eksistensi 
dari kekuasaan itu sendiri. Wacana meliputi sebuah sistem yang membentuk cara bagaimana melihat sebuah realitas; karena kata atau kalimat tidak mengasosiasikan kepada apa yang diketahui (pengetahuan tertentu), tetapi justru apa yang membatasi apa yang kita persepsikan (Jaya, 2016).

Berbicara wacana tidak bisa dilepaskan dari genealogi. Istilah genealogi didapatkan Foucault dari Nietsche. Namun keduanya memiliki perbedaan perlakuaan terhadap istilah tersebut. Nietsche menggunakan genealogi untuk membalikkan sesuatu hal yang khusus menjadi universal, sementara genealogi Foucault digunakan untuk membalikkan sesuatu yang marjinal seolaholah menjadi pusat. Genealogi berhubungan dengan sejarah, akan tetapi memiliki cara kerja yang berbeda dari yang digunakan oleh para sejarawan konvensional yang melacak asal atau kontinuitas. Genealogi melakukan dengan sebaliknya, menguraikan segala sesuatu yang awalnya dianggap saling berhubungan, yang menentukan sejarah masa kini, menjadi bagian-bagian yang memiliki keunikan masing-masing pada setiap zamannya dan tidak saling berhubungan. Selain itu, genealogi digunakan untuk mencari aturan-aturan pembentukan sejarah yang berbeda menjadi seolah-olah saling berhubungan dan saling mempengaruhi. Genealogicalogy repudiates this idea that there is behind events a guiding hand or set of regulating principles that determines how things progress and explains why the present is as it is (Prado, 2000). Genealogi menganggap apa yang menentukan masa kini hanyalah suatu konstruksi kekuasaan, menghubungkan sesuatu yang tidak berhubungan menjadi solah-oleh berkesinambungan dengan tujuan memberikan legitimasi bagi kekuasaan. Genealogi digunakan untuk melacak kompleksitas dan disparitas dari suatu sejarah, dengan membongkar makropartikular sejarah yang dianggap terbentuk karena mikropartikular, menjadi rincian partikular yang memiliki sejarahnya sendiri. Foucault mengatakan bahwa genealogi merupakan suatu kesatuan pengetahuan ilmiah dan ingatan lokal yang memperbolehkan kita membangun suatu pengetahuan historis mengenai perjuangan dan menjadikan pengetahuan ini secara taktis bangunan (Foucault, 2002). Melalui genealogi prosedur pembentukan wacana ' $\mathrm{TKI}$ ' dapat diketahui.

Pada prosedur pembentukan wacana dikenal juga dengan istilah eksklusi eksternal dan internal. Eksklusi berguna untuk memilahmilah mana wacana. Sehingga dalam hal ini akan ada pernyataan-pernyataan yang ditolak, dianggap benar dan salah, serta adanya kehendak untuk kebenaran itu sendiri. Berkaitan dengan eksklusi eksternal terdapat tiga hal yaitu larangan, pembagian (division) dan penolakan (rejections).

Larangan berkaitan dengan objek, ritual, dan hak berbicara, artinya tidak semua hal dapat dibicarakan, tidak semua tempat dapat digunakan untuk membicarakan sesuatu dan tidak semua orang boleh membicarakan-nya. Sementara penolakan, pembagian benar dan salah, serta kehendak kebenaran dapat dicontohkan dari apa yang dikatakan oleh orang gila. Keberadaan mereka dianggap tidak ada. Foucault mengatakan bahwa his word may be considered null and void, having neither truth nor importance, worthless as evidence in law, inadmissible in the authentification of deeds or contracts, incapable even of bringing about the trans-substantiation of bread into body at Mass (Foucault, 1981). 
Selain eksternal untuk dapat menelaah wacana TKI dalam novel Jatisaba perlu juga diketahui eksklusi internal atau aturanaturan yang ada dalam wacana itu sendiri yang terdiri dari komentar, pengarang dan disiplin, akan tetapi dalam hal ini eksklusi internal hanya akan disinggung berkaitan dengan komentar. Komentar berkaitan dengan narasi-narasi besar seperti teks keagamaan, teks hukum atau teks lain seperti sastra yang dianggap adiluhung yang sampai sekarang masih dijadikan hipogram bagi keberlangsungan sastra Indonesia. Komentar berperan untuk mengatakan apa yang ada dalam teks tersebut, dimodifikasi, diceritakan kembali, dan diulang yang kemudian memunculkan wacana baru yang dihubungkan dengan masa yang lebih kini, ditransformasikan dan dikatakan lagi secara tak terbatas (Jaya, 2016).

Pemaparan wacana di bagian sebelumnya, menunjukkan bahwa novel Jatisaba tidak dapat dilepaskan dari adanya wacana TKI. Selain itu, bahwa wacana tidak bisa dihindarkan dari adanya wacana tandingan, untuk itu perlu dilakukan pengkajian berkaitan dengan wacana dalam novel serta posisi novel Jatisaba dalam wacana TKI di Indonesia. Mengingat bahwa wacana tidak dapat dipisahkan dari sejarah dan kekuasaan, maka dalam penelitian ini juga dilakukan pengkajian secara genealogi berkaitan dengan penggunaan nama TKI. Tujuannya untuk mengetahui kekuasaan yang memproduksinya dan yang mengeksklusi wacana sebelumnya.

Sementara itu berkaitan dengan penelitian-penelitain sebelumnya yang menggunakan novel Jatisaba sebagai ojek material, sejauh ini belum pernah penulis temukan penelitian yang menggunakan pendekatan wacana sebagai objek formalnya. Untuk itu otentifikasi penelitian ini dapat dipertanggung jawabkan.

\section{Gambaran TKI dalam Novel Jatisaba}

Novel Jatisaba mengisahkan penduduk Desa Jatisaba yang memilih bekerja sebagai TKI. Mereka memilih menjadi TKI karena TKI dianggap sebagai solusi untuk menyelesaikan masalah kemiskinan yang mereka hadapi. Sebagai penyumbang devisa, kehidupan mereka jauh dari sejahtera karena sebagian besar warganya memilih menjadi TKI ilegal, sehingga bukan keuntungan yang mereka dapatkan melainkan kemalangan dan penderitaan yang lebih parah dari sebelumnya. Ironisnya, meski penduduk Jatisaba mengetahui penderitaan yang dialami oleh para TKI, mereka masih saja berkeinginan bekerja sebagai TKI. Untuk itu, bab ini akan menerangkan latar belakang calon TKI, cara TKI mendapatkan pekerjaan, dampak adanya pekerjaan sebagai TKI, dan pilihan-pilihan pacsa TKI.

\section{Latar Belakang Calon TKI dalam Novel Jatisaba}

Ada beberapa penduduk Jatisaba yang memilih bekerja sebagai TKI, yang pertama adalah Mae. Mae tinggal di Wilayah Tiban, wilayah yang dihuni oleh masyarakat yang memiliki kehidupan lebih baik. Wilayah Tiban kebanyakan dihuni oleh para pendatang yang bekerja sebagai Polisi, TNI, pegawai negeri, dan pegawai kantoran lainnya. Namun berbeda dengan keluarga Mae, Ayah Mae bekerja sebagai seorang botoh atau pendukung salah satu calon lurah. Sedangkan Ibu Mae mengandalkan tanaman euforbia untuk membantu perekonomian keluarganya. Meskipun keluarga Mae bukan keluarga kaya 
seperti kebanyakan warga Tiban, Mae mampu berkuliah dan memiliki gelar sarjana, dengan begitu dapat dikatakan bahwa secara ekonomi keluarganya tidak semiskin warga Jatisaba yang tinggal di Dulbur dan Legok.

"Kalau sekarang sudah berarti dulu belum. Tentu saja, semoga dalam benak ibu-ibu ini tidak tersimpan kenangan, bebarapa, dimana, dan dengan siapa saja dulu ibuku meninggalkan hutang. Dugaan itu membuatku tidak nyaman. Lebih baik mereka berterus terang di saat seperti ini, dan aku akan membayarnya tiga kali lipat..." (Akmal, 2017).

Kondisi keluarga dan perlakuan masyarakat kepada keluarga Mae tersebut, menimbulkan dendam dan disinyalir menjadi alasan Mae memutuskan untuk menjadi TKI. Setelah kepulangannya ke Jatisaba Mae bertekat untuk balas dendam kepada beberapa orang yang dahulu memusuhi keluarganya dengan cara menunjukkan kesuksesannya. Selain itu ketidaknyamanan terhadap lingkungan Jatisaba juga menjadi alasan Mae menjadi TKI. Dia adalah seorang lulusan sarjana yang secara pola pikir menginginkan tempat dan masyarakat yang mampu mendukungnya, sementara Jatisaba sendiri dihuni oleh masyarakat yang gemar berjudi, main perempuan, mabuk-mabukan serta pemalas. Hal tersebut yang menjadikan Mae merasa tidak nyaman. Selain itu, tidak tersedianya fasilitas umum yang memadai, juga menjadi pemicu Mae bekerja ke luar negeri.

Mae ada tokoh lain yang juga memilih untuk bekerja sebagai TKI, yaitu Sitas. Tokoh yang digambarkan bodoh, miskin, suka mencuri, dan berpendidikan rendah. Tidak hanya itu, Sitas selalu menjadi momok bagi Warga Jatisaba karena sifatnya yang tidak dapat dipercaya dan sering membuat kegaduhan akibat ulahnya yang gemar memfitnah sesama warga. Sitas memilih bekerja sebagai TKI, karena kemiskinan yang dialaminya serta adanya ajakan dari mantan pacar Sitas. Sitas dan keluarganya tinggal di rumah yang kumuh dan terbuat dari anyaman bambu. Sementara Pontu, suami Sitashanya bekerja sebagai penjual es cincau.

"Dulu aku diajak seorang tekong dari desa sebelah. Katanya dia bisa memberiku pekerjaa gampang dan gaji tinggi. Dia dulu kekasihku, Mae. Mana mungkin aku tak percaya. Dia juga berkata tak perlu susah-susah mengumpulkan biaya, apalagi meributkan surat-surat" (Akmal, 2017).

Jika Mae dan Sitas pernah menjadi TKI, Musri merupakan calon TKI yang akan dibawa oleh Mae. Musri adalah sahabat karib Mae semasa kecil. Suami Musri bekerja di kantin salah satu universitas dan ibunya memiliki ruko kecil di pasar sebagai tempat berjualan klepon. Kehidupan keluarganya jauh dari sejahtera. Hal itu tercermin dari keadaan rumah yang terbuat dari gedek atau bambu dan sering bocor ketika musim hujan.

"Seperti rumah orang legok lainnya, rumah Musri sepenuhnya adalah gedek. Dindingnya terbuat dari kepang yang dipaku pada kerangka bambu. Atapnya sebagian genting, tapi sebagian besar seng....mereka sibuk mondar-mandir membawa mangkuk-mangkuk untuk menampung air yang menetes dari atap yang bocor di sana-sini" (Akmal, 2017).

Alasan lain yang menjadi penyebab utama Musri memutuskan mengikuti Mae yaitu karena adanya paksaan dari Mbah Bangkring ibunya, yang menginginkan Musri bekerja ke luar negeri dengan tujuan agar Musri mampu melupakan kesedihannya setelah mengalami keguguran. Lebih dari itu karena ketidakmampuannya memberikan keturunan untuk suaminya sebab rahim Musri telah diangkat oleh bidan sehingga ia berharap dengan menjadi TKI, dapat mengikuti program bayi tabung. 
Calon lain yaitu Sanis yang juga merupakan teman masa kecil Mae meskipun secara usia dia lebih tua darinya. Alasan Sanis sama dengan kebanyakan calon TKI lainnya, yaitu faktor kemiskinan yang dialami sejak kecil dan keinginan untuk mempersiapkan masa depan bagi anaknya yaitu Kholik. Hal itu terlihat dari keadaan rumah Sanis dan keluarganya yang berada di tengah sawah yang tidak layak huni. Selain itu cara penghiupan keluarga tersebut terbilang tidak wajar.

Jika Musri dan Sanis dikategorikan sebagai babon oleh Mae yang akan dipekerjakan sebagai pembantu rumah tangga dan buruh kasar, Gebong adalah dere yang nantinya akan dipaksa menjadi PSK. Permusuhan antar keluarga Gebong dan Bangkring menjadi alasan kuat Gebong ingin menjadi TKI, dengan harapan ia dapat menandingi kekayaan keluarga Bangkring. Selain Gebong, dere yang akan dibawa oleh Mae adalah Guteng. Guteng menjadi TKI karena paksaan dari Kasem yang menanggung rasa malu karena Guteng merupakan anak hasil perselingkuhan Darto dengan teman kerjanya yang kemudian diasuh oleh Kasem istri sah Darto.

Secara keseluruhan faktor ekonomi dan faktor rendahnya pendidikan menjadi alasan bagi penduduk Jatisaba memilih bekerja sebagai TKI. Namun alasan lain menjadi TKI juga karena adanya paksaan dari anggota keluarga, dendam terhadap sesama warga, kecangihan teknologi, dan mempersiapkan masa depan bagi anak, menjadi alasan lain penduduk Jatisaba memutuskan bekerja sebagai TKI.

\section{Cara TKI Mendapatkan Pekerjaan}

Cara para TKI mendapatkan pekerjaan yaitu melalui peran Calo. Sitas menerima tawaran dari mantan kekasihnya yang bekerja sebagai calo TKI, sedangkan Musri, Gebong, Gutheng, Sanis, Saniah, dan beberapa TKI yang berasal dari Kampung sebelah Jatisaba, menjadi TKI melalui peran Mae. Mae tidak bekerja sendiri dalam misinya tersebut. Dia menjalin kerja sama dengan beberapa pihak di antaranya Jompro, calon lurah Desa Jatisaba. Mae mendapatkan tambahan dana dari Jompro dengan syarat Mae harus membantu Jompro untuk meyakinkan penduduk Jatisaba agar memilihnya dipemilihan Lurah Jatisaba.

Perkenalan Mae dengan Jompro ini menghubungkannya dengan Lurah Jatisaba yang masih menjabat dan Dikin, sekertaris lurah sekaligus keponakan dari Jompro. Darinya dia mendapatkan kemudahan pengurusan surat-surat yang nantinya akan digunakan oleh Mae untuk meyakinkan para calon TKI. Selain adanya kerjasama dengan beberapa penduduk, keberhasilan Mae meyakinkan konstituennya yaitu dengan menampilkan diri yang sukses setelah menjadi TKI. Hal itu terlihat dari kesan priyayi yang ia tunjukkan, kedermawanan kepada beberapa penduduk Jatisaba, dan memiliki pacar pegawai kantoran yang kaya. Apa yang dilakukan oleh Mae tersebut mendapatkan respon dari beberapa penduduk Jatisaba, yang dengan begitu wacana TKI berhasil didistribusikan.

Dengan demikian cara yang dilakukan oleh Mae sebagai calo untuk melancarkan misinya yaitu pertama dengan mengadakan kerja sama dengan pemilik kuasa yaitu Jompro, Lurah, Sekertaris Desa Jatisaba, dan Malim yang membantu praktik penyuapan terhadap lurah. Cara yang kedua yang digunakan dalam merekrut calon TKI yaitu melalui pemanfaatan pengetahuan yang dimilikinya. Ketiga dengan menunjukkan perubahan penampilan fisik dan sikap. Perubahan fisik yang ditunjukkan dengan mempercantik diri dan gaya 
berpakaian modern. Sementara perubahan sikap ditunjukkan melalui kedermawan ketika berada di ranah publik. Yang keempat yaitu melalui pengakuan transformasi pekerjaan Mae dari seorang TKI menjadi pegawai kantoran perekrut calon TKI, dan yang terakhir adanya penyampaian berita oleh Bangkring tentang kesuksesan Mae kepada penduduk Jatisaba.

\section{Wacana TKI dari Masa ke Masa dan Komentar Ramayda Akmal sebagai Penulis Era Soekarno}

Pada era kepemimpinan Soekarno TKI belum dibicarakan bahkan tidak dibahas dalam undang-undang. Di masa kepemimpinan Soekarno hanya dikenal istilah buruh yang penjelasannya terdapat dalam undang-undang Nomor 33 Tahun 1947 Tentang Buruh, Kecelakaan. Undangundang Kecelakaan 1947. Pembayaran ganti kerugian ke pada buruh yang mendapat kecelakaan berhubung dengan hubungan kerja. Istilah 'buruh' definisikan pada Pasal 6 yang berbunyi tiap- tiap orang yang bekerja pada majikan di perusahaan yang diwajibkan memberi tunjangan dengan mendapat upah (UU RI, 1947). Dari definisi tersebut maka buruh adalah mereka yang bekerja pada majikan di suatu perusahaan dan perusahaan tersebut diwajibkan untuk memberikan tunjangan berupa upah.

\section{Era Soeharto}

Di era Soeharto istilah 'Buruh' diganti dengan kata 'Tenaga Kerja'. Hal itu karena buruh dianggap identik dengan pertentangan kelas. Melihat dari kaca mata sejarah, bahwa pernah terjadi pergerakan yang dilakukan oleh buruh untuk menggulingkan kekuasaan kapitalis dengan tujuan mewujudkan masyarakat sosialis yang sama rasa sama rata. Sementara di Indonesia sendiri istilah buruh mengingatkan pada mobilisasi masa yang dilakukan oleh penguasa berideologi komunis untuk melakukan perlawanan terhadap pemerintahan yang sah. Hal itulah yang mungkin menjadi pertimbangan pemerintah Soeharto untuk mengubah istilah buruh menjadi tenaga kerja karena sering kali buruh dikaitkan dengan gerakan politik, revolusi sosial, perjuangan kelas seperti yang telah di paparkan di paragraf sebelumnya.

Sementara jika ditinjau dari arah kebijakan ekonomi, Soekarno menerapkan sistem ekonomi terpimpin yang merupakan turunan dari sistem politik yang digunakan di Indonesia menjelang dekade 1960-an yaitu Demokrasi Terpimpin. Sistem ekonomi terpimpin dianut negara-negara Blok Timur, seperti Rusia atau Cina yang berideologi sosialis. Sementara Soeharto lebih Pro Barat yaitu kapitalis. Dengan begitu, pengantian tersebut syarat dengan nuansa politik. Namun pengantian kata buruh dengan tenaga kerja, makin menunjukkan bahwa Soeharto berupaya untuk melindungi kapitalis, dengan menjadikan tenaga kerja sebagai modal kapitalis.

Pergantian istilah buruh dengan tenaga kerja juga bertujuan untuk menghapus konotasi komunis, revolusi, pergerakan kelas, yang ada pada istilah buruh dengan cara menggunakan istilah tenaga kerja. Namun istilah tenaga kerja memiliki cakupan yang luas, karena setiap orang yang memiliki tenaga untuk bekerja termasuk dalam definisi tenaga kerja. Cakupan yang luas tersebut, buruh tidak lagi penting di era Soeharto, padahal menurut Marxis buruh merupakan kekuatan utama dalam masyarakat yang mampu menciptakan perubahan sosial dan menciptakan sejarah. Di era Soeharto yang dipentingkan hanyalah 
tenaga dari buruh. Adanya pengantian tersebut maka, makna dan kekuatan buruh tereduksi. Buruh di masa Orde Baru hanya menjadi bagian kecil dari tenaga kerja padahal di awal buruh memiliki hak istimewa. Di masa Orde Baru buruh hanya ditempatkan sebagai bagian dari alat produksi, sebagai modal dari kapitalis dan pengantian tersebut bersifat eksploitatif serta politis.

Pergantian istilah buruh dengan tenaga kerja juga meniadakan subjek, pasalnya yang dimaksud tenaga kerja yaitu 'tenaga yang digunakan untuk bekerja' sehingga yang dipentingkan hanyalah 'tenaganya' bukan 'orangnya'. Sementara 'buruh' pada era Soekarno memiliki makna yang lebih mengedepankan subjek bukan objek/ tenaganya saja. Perumusan Undang-Undang Nomor 14 Tahun 1969 Tentang Tenaga Kerja di pemerintahan Soeharto di antaranya berbunyi bahwa tenaga kerja merupakan modal utama serta pelaksanaan dari pada pembangunan masyarakat Pancasila. Sementara definisi Tenaga Kerja pada Pasal 1 undang-undang tersebut, Tenaga Kerja adalah tiap orang yang mampu melakukan pekerjaan baik di dalam maupun di luar hubungan kerja guna menghasilkan barang dan jasa (UU RI, 1969). Jika dibandingkan dengan pengertian Buruh era Soekarno yang diartikan tiap-tiap orang yang bekerja pada majikan di perusahaan yang diwajibkan memberi tunjangan dengan mendapat upah maka keduanya memiliki perbedaan yang signifikan. Pasalnya penggunaan kata buruh menunjuk pada subjek atau orang sementara tenaga kerja lebih merujuk barang atau benda abstrak yang berupa tenaga yang dapat digunakan untuk bekerja. Dari perbedaan kedua term tersebut maka kata buruh pada era Soekarno lebih mengedepankan subjek atau orang, sementara istilah tenaga kerja yang digunakan pada pemerintahan Soeharto lebih merujuk kepada tenaga yang dapat dijadikan sebagai modal untuk pembangunan masyarakat pancasila. Dengan kata lain bahwa buruh yang digunakan oleh Soekarno lebih nguwonge wong, ketimbang tenaga kerja yang tidak menganggap keberadaan subjek melainkan lebih mementingkan benda abstrak yang berupa tenaga.

Sementara yang dimaksud dengan adanya hubungan kerja atau di luar hubungan kerja dalam definisi tersebut yaitu pekerjaan dilakukan secara formal, maupun informal, baik melalui adanya kontrak atau perjanjian kerja maupun tidak didasari adanya kontrak kerja. Jadi TKI masuk ke dalam definisi tenaga kerja yang cakupannya luas.

Barulah pada peraturan Menteri Tenaga Kerja Republik Indonesia Nomor: PER-01/ MEN/1991 Tentang Antar Kerja Antar Negara pada Pasal 1 c memuat definisi Tenaga Kerja Indonesia secara khusus, bunyi pasal tersebut yaitu Tenaga Kerja Indonesia yang selanjutnya disebut TKI adalah Warga Negara Indonesia baik laki-laki maupun perempuan yang melakukan kegiatan ekonomi, sosial dan budaya atau mengikuti pelatihan sambil bekerja di luar negeri dalam jangka waktu tertentu berdasarkan perjanjian kerja (Peraturan Menteri, 1991).

Kemunculan istilah tenaga kerja Indonesia (TKI) dalam peraturan Menteri Tenaga Kerja Republik Indonesia Nomor: PER-01/ MEN/1991 Tentang Antar Kerja Antar Negara tersebut menandakan pertama kalinya istilah tersebut digunakan. TKI dalam permen tersebut diartikan sebagai warga negara Indonesia baik laki-laki maupun perempuan 
yang melakukan kegiatan ekonomi, sosial, budaya atau mengikuti pelatihan sambil bekerja di luar negeri dalam jangka waktu tertentu dan dengan adanya hubungan kerja. Dengan adanya poin hubungan kerja maka penempatan mereka harus dilakukan secara formal atau melalui kontrak kerja. Akan tetapi, definisi tersebut memiliki cakupan yang sangat luas, pasalnya semua orang yang berkewarganegaraan Indonesia dalam melakukan hubungan ekonomi, sosial, budaya dan pelatihan yang dilakukan sembari bekerja dan dengan adanya hubungan kerja, dianggap sebagai TKI. Sebagai contoh musisi atau budayawan yang melakukan pertunjukan di luar negeri dalam jangka waktu tertentu dan adanya perjanjian atau kontrak kerja menurut definsisi tersebut digolongkan sebagai TKI. Dengan kemunculan istilah TKI pertama kali di Orde Baru, menjadi suatu bentuk perluasan ekonomisasi tenaga kerja Indonesia sampai ke luar negeri.

Masih di Orde Baru pemerintah melalui Undang-Undang Nomor 25 Tahun 1997 Tentang Ketenagakerjaan juga mengatur tenaga kerja yang awalnya di dalam definisi tersebut memuat pengertian TKI, dengan berlakunya dua undang-undang tersebut pemerintah memisahkan antara tenaga kerja di dalam negeri dengan TKI. Bunyi Pasal 1 adalah setiap orang laki-laki atau wanita yang sedang dalam dan/atau akan melakukan pekerjaan, baik di dalam maupun di luar hubungan kerja guna menghasilkan barang atau jasa untuk memenuhi kebutuhan masyarakat (UU RI, 1997). Poin penting dalam Undang-Undang Ketenagakerjaan tersebut yaitu bahwa setiap orang Indonesia yang sedang dalam proses mencari pekerjaan dan sedang melakukan pekerjaan baik dilakukan secara formal maupun informal ketika mereka memiliki kemampuan untuk menghasilkan barang atau jasa baik untuk orang lain maupun dirinya sendiri disebut sebagai tenaga kerja. Definisi tersebut memiliki cakupan yang luas. Namun meski begitu berbeda dengan TKI.

Dengan adanya pemisahan antara TKI dengan tenaga kerja dalam negeri, maka kemunculan TKI mengeksklusi tenaga kerja dalam hal hubungan kerja. Pengerahan tenaga kerja di dalam negeri boleh dilakukan secara formal maupun informal. Sementara penempatan TKI harus dilakukan secara formal atau adanya hubungan kerja. Sedangkan yang berhak melakukan pengerahan dan penempatan TKI yaitu pemerintah melalui PPTKI atau badan usaha yang berbentuk badan hukum kepada pengguna jasa tenaga kerja. Syarat adanya hubungan kerja tersebut, maka pemerintah dan perusahaan swasta yang memiliki izin dari pemerintah, memiliki hak mengerahkan dan menempatkan TKI. Tujuannya agar pemerintah dapat melakukan kontrol sekaligus memberikan perlindungan kepada TKI di luar negeri.

\section{Era Reformasi}

Pemakain TKI terus dilanjutkan hingga masa Reformasi meskipun dengan pendefinisian yang terus diperbarui, akan tetapi esensi buruh sebagai seorang manusia yang bebas telah dipersempit dengan hanya mementingkan tenaganya. Seperti di era Presiden B.J. Habibi, dalam pemerintahannya yang sangat singkat, Habibi mengeluarkan Kerpres Nomor 29 Tahun 1999. Definisi TKI dalam Kepres tersebut diatur dalam Pasal 1b yang berbunyi Tenaga Kerja Indonesia yang selanjutnya disebut TKI adalah tenaga kerja yang melakukan pekerjaan dalam hubungan 
kerja maupun pelatihan sambil bekerja di luar negeri untuk jangka waktu tertentu berdasarkan perjanjian kerja tertulis dan prosedur pelayanan penempatan tenaga kerja yang berlaku (Presiden, 1999). Perpres tersebut mengeksklusi definisi TKI di masa Soeharto dalam hal tujuan bekerja atas dasar ekonomi, sosial, budaya, digantikan dengan melakukan pekerjaan yang memiliki arti yang luas. Selain itu juga terdapat penambahan 'bagi orang Indonesia yang mengikuti pelatihan yang dilakukan sambil bekerja' dalam jangka waktu tertentu di luar negeri, juga disebut sebagai TKI. Sementara maksud melalui prosedur pelayanan yang berlaku yaitu penempatan TKI dilakukan oleh Badan Koordinasi Penempatan Tenaga Kerja Indonesia (BKPTKI) yang merupakan lembaga non-struktural yang bertugas untuk melakukan penempatan TKI. Sementara dalam undang-undang era Soeharto penempatan tenaga kerja dilakukan oleh pemerintah dan perusahaan swasta yang memiliki izin dari pemerintah dan diatur dalam PER-01/MEN/1991 tentang Antar Kerja Antar Negara.

Pemerintahan Abdurrahman Wahid masih menggunakan undang-undang TKI yang sama dengan era Habibi sehingga eksklusi yang dilakukan oleh pemerintah Abdurrahman Wahid berkaitan dengan TKI juga masih sama dengan yang dilakukan pemerintahan Habibi. Yang membedakan di masa Gus Dur dengan Habibi ialah dikeluarkannya Undang-Undang Nomor 21 Tahun 2000 Tentang Serikat Buruh Serikat Pekerja. Undang-undang tersebut memberikan kebebasan kepada buruh atau pekerja untuk membentuk perserikatan. Buruh dan pekerja didefinisikan sama dengan pekerja, pekerja/buruh adalah setiap orang yang bekerja dan menerima upah atau imbalan dalam bentuk lain (UU RI, 2000). Pendefinisian yang sama antara pekerja/buruh di masa Gus Dur, seakan-akan ingin mengakomodasi keduanya padahal kedua kata tersebut sejak awal kemunculannya memiliki pengertian yang berbeda, pekerja disamakan dengan tenaga kerja, sementara buruh adalah subjek manusia. Dengan demikian telah terjadi pengaburan makna dalam penyamaan definisi tersebut.

Era Megawati dan Susilo Bambang Yudhoyono menggunakan Undang Undang TKI yang sama yang diatur dalam undang-undang Nomor 39 Tahun 2004 Tentang Penempatan dan Perlindungan Tenaga Kerja Indonesia di Luar Negeri. TKI dalam UU tersebut didefinisikan pada Pasal 1 angka 1, Tenaga Kerja Indonesia yang selanjutnya disebut dengan TKI adalah setiap warga negara Indonesia yang memenuhi syarat untuk bekerja di luar negeri dalam hubungan kerja untuk jangka waktu tertentu dengan menerima upah (UU RI, 2004). Definisi TKI tersebut memiliki perbedaan dengan era Soeharto dan Habibi. Di masa Soeharto, TKI diartikan sebagai Warga Negara Indonesia baik laki-laki maupun perempuan yang melakukan kegiatan ekonomi, sosial dan budaya atau mengikuti pelatihan sambil bekerja di luar negeri dalam jangka waktu tertentu berdasarkan perjanjian kerja. Sementara di era Habibi TKI diartikan sebagai tenaga kerja yang melakukan pekerjaan dalam hubungan kerja maupun pelatihan sambil bekerja di luar negeri untuk jangka waktu tertentu berdasarkan perjanjian kerja tertulis dan prosedur pelayanan penempatan tenaga kerja yang berlaku.

Yang membedakan istilah TKI di masa Megawati dan SBY dengan masa Soeharto yaitu TKI diartikan sebagai seseorang yang sudah 
memenuhi syarat untuk bekerja ke luar negeri, baik yang sudah bekerja atau belum bekerja, asalkan mereka memenuhi syarat untuk bekerja di luar negeri dalam definisi era Megawati dikategorikan sebagai TKI. Syarat yang dimaksud bukan hanya usia melainkan juga kelengkapan dokumen dan proses yang harus mereka tempuh agar dinyatakan layak bekerja di luar negeri. Dengan terpenuhinya syarat-syarat yang dimaksud maka mereka dikategorikan sebagai TKI resmi atau legal. Namun di era Megawati tidak dicantumkan bekerja ke luar negeri atas dasar mengikuti pelatihan dan di sinilah yang membedakan definisi TKI di era Megawati dengan era Habibi. Selain itu landasan bekerja di luar negeri di masa Megawati tidak hanya berkaitan dengan ekonomi, sosial, budaya atau pelatihan sambil melakukan pekerjaan di luar negeri. Sehingga Megawati mengeksklusi tujuan bekerja atas dasar ekonomi, sosial, budaya atau pelatihan. Selain itu masalah penempatan juga tidak dicantumkan dalam definisi tersebut, padahal di masa Habibi penempatan TKI dilakukan oleh Badan Koordinasi Pengerahan Tenaga Kerja Indonesia (BKPTKI).

Pemerintahan Susilo Bambang Yudhoyono (SBY) menggunakan undangundang yang sama dengan yang digunakan oleh Megawati. Hal itulah yang menjadikan definisi Tenaga Kerja Indonesia di luar negeri tidak ada perubahan. SBY dalam pemerintahannya juga mengeluarkan Peraturan Pemerintah Nomor 4 Tahun 2013 yang definisinya sama dengan undangundang Nomor 39 Tahun 2004. Di era pemerintahan SBY dibentuklah (Badan Nasional Penempatan dan Perlindungan Tenaga Kerja Indonesia) BNP2TKI untuk mengatur penempatan perlindungan TKI Indonesia.

Di era SBY dan Megawati syarat-syarat TKI mengeksklusi definisi TKI di era sebelumnya yang tidak mencantumkan syarat-syarat. Sementara penempatan TKI yang awalnya dilakukan oleh BKPTKI di era Mega SBY dilakukan oleh BNP2TKI. Dengan adanya syarat yang harus dipenuhi maka TKI yang dianggap benar yaitu TKI yang memiliki kelengkapan dokumen dan telah melalui proses pelatihan, pengecekan kesehatan psikologi, dan penempatan dilakukan oleh BNP2TKI.

Penggunaan istilah buruh oleh Soekarno, merupakan suatu usaha pemerintah untuk memanusiakan manusia dengan mementingkan subjek ketimbang objek. Namun di era Soeharto hingga reformasi istilah buruh tereksklusi oleh tenaga kerja. Buruh yang awalnya mendapat hak istimewa, hanya dijadikan bagian kecil dari tenaga kerja atau buruh tidak lagi dipentingkan oleh pemerintahan Soeharto. Penggantian dilakukan karena adanya unsur politik, mereduksi makna kekuatan buruh, lebih mementingkan tenaga ketimbang subjek dan bersifat eksploitatif. Dengan digunakannya tenaga kerja maka pemerintah menjadikan mereka sebagai komoditas, yang diperdagangkan guna mendapatkan keuntungan. Selain itu, pemakaian istilah tenaga kerja Indonesia di luar negeri dari masa Soeharto sampai SBY menunjukkan bahwa, ekonomisasi terhadap TKI sudah dilakukan sejak zaman Orde Baru sampai dengan era reformasi di zaman SBY. Dengan lebih mengutamakan tenaga atau objek dibandingkan dengan subjek, menunjukkan bahwa penguasa sejak Orde Baru sampai SBY hanya mementingkan tenaganya ketimbang orangnya, dan menjadikan mereka sebagai objek atau komoditi untuk mendapatkan 
keuntungan bagi negara.

\section{Komentar Ramayda sebagai Penulis}

Komentar dalam pembentukan suatu wacana memiliki dua peran yaitu menjaga adanya hirarki antara teks primer dengan sekunder, dan menyebabkan adanya konstruksi wacana baru dari hasil interpretasi seseorang. Komentar dapat dikatakan sebagai suatu bentuk pengulangan terhadap sebuah pernyataan, akan tetapi dalam pengulangan tersebut ada penyimpangan karena hasil interpretasi seseorang sehingga melahirkan wacana baru.

Dalam kaitannya dengan pembahasan di bagian sebelumnya mengenai wacana TKI pemerintah dan luar pemerintah, Ramayda sebagai seorang penulis melakukan pengulangan terhadap kedua wacana tersebut yang kemudian dituliskan dalam novel Jatisaba, komentar-komentar tersebut di antaranya terlihat dalam kutipan di bawah ini.

"Tapi kampungmu itu pemasok devisa terbesar di kabupaten ini. Itu membangakan. "lelaki itu berkata sambil membuka topinya. Melihat kepalanya yang nyaris botak dan pakaian safarinya yang sedikit kekecilan mengingatkanku pada pegawai di desa atau kecamatan. Perutnya tampak melembung. Dan ada Cartier di pergelangan yangannya. Cuma pegawai korupsi yang bisa membelinya" (Akmal, 2017).

TKI sebagai sumber devisa merupakan wacana yang berasal dari pemerintah. Bahkan pemerintah memberikan gelar kepada mereka sebagai pahlawan devisa, karena begitu banyaknya sumbangan yang mereka berikan kepada pemerintah. Selain itu, tujuan pemerintah melakukan penempatan dan memberikan perlindungan pada para TKI-nya agar selain mampu mengurangi angka pengangguran, meningkatkan kesejahteraan, juga agar pemerintah mendapatkan sumbangan devisa yang lebih dari adanya TKI tersebut. Namun pengulangan wacana TKI dari pemerintah oleh Ramayda tersebut dihubungkan dengan pegawai yang melakukan korupsi. Hal tersebut menjadi suatu bentuk penyimpangan wacana yang dilakukan oleh Ramayda. Pasalnya korupsi merupakan suatu wacana tersendiri yang sampai saat ini masih belum mampu dituntaskan oleh pemerintah.

Pengulangan wacana TKI menurut pemerintah yang dilakukan oleh Ramayda, juga terdapat pada kutipan di bawah ini,

Kenapa semua itu bisa terjadi, ibu-ibu? Karena mereka ilegal. Mereka tidak mempunyai perlindungan hukum sehingga bisa seenaknya diperlakukan oknum tak bertanggungjawab. Karena ilegal, mereka juga tidak berani melapor karena akan mendapat penderitaan yang berlipat ganda atas pelanggaran tersebut. siksaan lahir batin, ibu-ibu" (Akmal, 2017).

TKI ilegal merupakan wacana yang dieksklusi oleh pemerintah, mereka tidak mengatur hal tersebut. TKI yang bekerja sesuai dengan prosedur dari pemerintah, disebut sebagai TKI legal. Meskipun dalam undangundang tidak di katakan secara langsung TKI legal, akan tetapi dengan adanya peraturan, ketentuan, syarat dan prosedur yang harus dilalui oleh seseorang untuk bekerja ke luar negeri, maka hal tersebutlah yang dikategorikan sebagai TKI legal atau resmi. Dengan begitu Ramayda dalam kutipan tersebut mengulang wacana TKI dari pemerintah yaitu TKI legal yang memiliki perlindungan hukum, sehingga jika terjadi sesuatu pada mereka maka pemerintah dapat membantu mereka. Selain mendapatkan perlindungan hukum, para TKI legal juga akan mendapatkan pemantauan dari pihak pemerintah. Pemerintah menyiapkan kantor 
pengaduan apabila terjadi sesuatu pada mereka, maka para TKI dapat mengadu kepada perwakilan pemerintah di negara yang bersangkutan, seperti pada kutipan berikut ini,

"di setiap tempat ibu bekerja, ada kantor cabag kami yang akan mengontrol kinerja ibu dan tetntu saja menerima segala keluhan dan laporan jika ada tindakan-tindakan kekerasan terhadap pekerja" (Akmal, 2017) .

Wacana TKI dari pemerintah bertujuan untuk memberikan kesejahteraan bagi penduduknya. Hal itu yang diulang oleh Ramayda dalam novelnya sebagai berikut, “...Kau bisa lihat nasib lasinem, dia kaya raya dan sehat bugar setelah pulang bekerja di Hongkong. Aku memang sial," Sitas mulai bercerita (Akmal, 2017).

Dalam novel Jatisaba Ramayda juga melakukan komentar terhadap wacana TKI yang ada di luar pemerintah. Wacana di luar pemerintah banyak membahas tentang kasus -kasus yang dialami oleh TKI Indonesia khususnya yang ilegal. Mereka sering menjadi objek kekerasan baik dari majikan maupun dari teman yang mereka temui di luar negeri. Tidak jarang dari mereka sering kali menjadi objek pelecehan seksual hingga akhirnya hamil tanpa pertanggung jawaban. Pada kutipan tersebut diceritakan bahwa banyak warga Jatisaba yang menjadi objek pemerkosaan hingga hamil di luar nikah. Selain itu menjadi TKI memang dapat mengubah taraf kehidupan seseorang, akan tetapi tidak ada jaminan dapat berlangsung lama tanpa kembali lagi bekerja menjadi TKI. Hal itu perlu dilakukan agar apa yang telah mereka miliki dapat dipertahankan.

Banyak TKI yang dipekerjakan sebagai PSK, Khairudin Harabap dalam bukunya Menitih Buih Ke Malaysia- Khairudin Harahap dan Pekerja Indonesia, melaporkan bahwa banyak TKI Indonesia yang di jadikan sebagai pelacur di Malaysia oleh para sindikat. Mereka awalnya ditawari pekerjaan sebagai pembantu, akan tetapi kemudian dijebak sebagai pelacur (Khairudin, 1998). Kasus penjerumusan TKI pada praktik prostitusi tersebut yang di ulang oleh Ramayda dalam novelnya. Wacana tersebut merupakan wacana yang lahir di luar wacana TKI dari pemerintah, akan tetapi dalam pengulangan tersebut terjadi penyimpangan wacana yang akhirnya melahirkan wacana baru.

TKI ilegal adalah TKI yang tidak sesuai dengan prosedur dari pemerintah mereka memang sering dijebak untuk bekerja sebagai pelacur, akan tetapi dalam pengulangannya Ramayda menambahkan bumbu-bumbu penyimpangan seksual yang dilakukan oleh Tuan Kim yang menyiksa dirinya ketika berhubungan intim. Penyimpangan seksual Tuan Kim tersebut dinamakan sadisme yaitu kepuasan seks yang didapat dengan menyiksa pasangan baik secara fisik atau psikologis dan hal tersebut dapatmembawa kesenangan bagi pelakunya (Metekohy, 2016). Dengan begitu pengulangan wacana TKI yang dilakukan oleh Ramayda tersebut menghadirkan wacana baru yang berkaitan dengan seks sadisme.

Meskipun novel Jatisaba mengulang wacana dari pemerintah dan luar pemerintah, tapi akhir dari novel tersebut tidak memberikan solusi apa pun terhadap keberadaan TKI. Dikisahkan di akhir bahwa Mae dan calon TKInya, berhasil digagalkan oleh polisi, Mae dipenjara sementara para calon TKI-nya dipulangkan ke Jatisaba. Namun keberadaan Mayor Tua, Tuan Kim di luar sana tetap menghirup udara bebas tanpa tersentuh oleh hukum, dengan begitu tidak menutup kemungkinan akan lahir Mae-Mae baru yang menjadi calo TKI. Dengan demikian Wacana 
TKI ilegal di Indonesia belum bisa dihapuskan. Dengan tanpa menawarkan solusi baru dan kecenderungan berpihak pada TKI legal yang sesuai dengan wacana TKI yang di narasikan oleh pemerintah maka posisi Jatisaba sebagai novel berada pada wacana pemerintah yaitu Anda boleh menjadi TKI namun harus resmi sesuai dengan peraturan pemerintah agar tidak menjadi korban humman traficking.

\section{Simpulan}

Wacana TKI di Indonesia di mulai sejak Indonesia dipimpin oleh Soeharto. Pada era kepemimpinan Soekarno TKI belum dibicarakan bahkan tidak dibahas dalam undang-undang. Zaman Soekarno masih digunakan istilah buruh, akan tetapi di zaman Soeharto sampai dengan SBY istilah buruh diganti dengan istilah 'tenaga kerja'. Penggantian tersebut karena beberapa alasan yaitu adanya unsur politik, mereduksi makna dan kekuatan buruh, serta komersialisasi manusia. Selain itu, penghapusan tersebut juga karena arah kebijakan ekonomi yang berbeda, Soekarno lebih dekat dengan Sosialis, sementara Soeharto sampai dengan SBY pro dengan kapitalis. Padahal jika dilihat dari etimologi istilah buruh, Soekarno lebih mengutamakan subjek atau orang ketimbang tenaga kerja yang digunakan oleh Soeharto. Dengan Kata lain Soekarno lebih nguwonge wong, dari pada Soeharto yang hanya mementingkan tenaga yang mereka miliki dibanding dengan subjek itu sendiri. Soeharto hanya menjadikan mereka sebagai alat produksi kapitalis untuk mendapatkan keuntungan.

Dari masa ke masa banyak terjadi kasuskasus yang dialami oleh TKI, akan tetapi hal tersebut dieksklusi oleh wacana pemerintah, dengan begitu wacana TKI pemerintah tidak mengakomodasi TKI sebagai objek dan TKI ilegal. Wacana TKI sebagai objek dan ilegal muncul dari media, NGO, serta kajian akademik. Wacana TKI di luar pemerintah banyak menceritakan nasib TKI yang menjadi objek kejahatan kemanusiaan baik ketika mereka berada di luar negeri maupun ketika mereka masih di dalam negeri, dari proses perekrutan sampai kepulangan mereka kembali.

Berdasarkan penjelasan mengenai wacana TKI dari pemerintah dan wacana TKI di luar pemerintah, serta komentar yang dilakukan Ramayda sebagai penulis terhadap wacana TKI, menjadikan novel Jatisaba karya Ramayda Akmal tersebut, solah-olah berada pada wacana TKI di luar pemerintah, karena dalam novel tersebut lebih banyak menceritakan kasuskasus yang dialami oleh TKI ilegal yang dieksklusi oleh TKI menurut pemerintah. Wacana dalam novel Jatisaba memaknai TKI ilegal sebagai korban kejahatan kemanusiaan. Namun adanya dua tokoh sebagai representasi TKI legal yang mendapatkan kesuksesan, mengindikasikan bahwa novel Jatisaba menyetujui wacana TKI dari pemerintah yaitu menjadi TKI legal. Untuk menjadi TKI legal seseorang harus memenuhi syarat dan sesuai dengan prosedur yang telah ditetapkan oleh pemerintah, sehingga nantinya mereka akan mendapatkan perlindungan. Dengan perlindungan tersebut diharapkan kepulangan mereka ke tanah air, akan membawa dampak positif dan mampu mengubah kehidupannya menjadi lebih baik. Dengan demikian jelas bahwa posisi novel ada dalam wacana kekuasaan yaitu menyetujui adanya TKI legal, yang notabenenya ilegal maupun legal keduanya sama saja yaitu sebagai modal kapitalis.

Novel Jatisaba masih meninggalkan 
Poetika : Jurnal Ilmu Sastra

Vol. 8 No. 1, Juli 2020
DOI 10.22146/poetika.56541

ISSN 2338-5383 (print) ; 2503-4642 (online) permasalahan. Cerita pada bagian terakhir novel tersebut yaitu tokoh yang tertangkap oleh polisi dalam praktik percaloan TKI ilegal hanya Mae dan Malim, padahal yang menjadi dalang dari semua itu adalah Mayor Tua. Dengan begitu Ramayda menganggap bahwa menjadi TKI itu boleh asalkan secara resmi, karena praktik percaloan TKI ilegal itu masih terus terjadi. Hal tersebut membuktikan bahwa novel Jatisaba tidak menawarkan solusi apa pun serta makin menguatkan posisi novel yang berada di dalam wacana TKI menurut kekuasaan.

Dalam novel Ramayda melakukan komentar terhadap wacana TKI baik dari pemerintah maupun luar pemerintah. Wacana TKI menurut pemerintah yaitu TKI sebagai sumber devisa, sebagai solusi mendapatkan kekayaan, dan mengubah taraf hidup seseorang. Sementara pengulangan wacana TKI di luar pemerintah di antaranya TKI ilegal dipekerjakan sebagai PSK, mendapat siksaan sewaktu dalam pemberangkatan, mendapat perlakuan tidak menyenangkan dari teman, menjadi objek pemerasan, korban pemerkosaan, objek perdagangan organ tubuh manusia, dan gaji tidak dibayarkan. Dalam melakukan komentar terhadap wacana TKI, terdapat beberapa penyimpangan yang dilakukan oleh Ramayda sehingga menimbulkan wacana baru yaitu wacana pejabat yang korup, seks sadisme atau rasa puas dalam melakukan hubungan intim jika melihat lawannya menderita.

\section{Daftar Pustaka}

Akmal, R. 2017. Jatisaba. PT Grasindo.

Faruk. 2017. Metode Penelitian Sastra-Sebuah Penjelajahan Awal. Pustaka Pelajar.

Foucault, M. 1981. Untying The Text: A PostStructuralist Reader. Routledge \& Kegen.

Foucault, M. 2002. Power/Knowledge. Bentang Budaya.

Jaya, A. 2016. Produksi, Distribusi, dan Kontestasi Wacana Tradisi dan Moderenitas dalam Cerpen Leteh Karya Oka Rusmini. Poetika, IV(2), 109.

Khairudin, H. 1998. Menitih Buih Ke MalaysiaKhairudin Harahap dan Pekerja Indonesia 1991-1198. Indonesian Sosiology Research.

Metekohy, M. 2016. Mengenal 10 Jenis Penyimpangan Seksual. Kompas.Com. https://lifestyle.kompas.com/ $\mathrm{read} / 2016 / 09 / 19 / 211500823 /$ mengenal.10.jenis.penyimpangan.seksua l?page=3 diakses pada 11 Juli 2019 pukul 18.00 WIB.

Peraturan Menteri. 1991. PER-01/MEN/1991 Tentang Antar Kerja Antar Negara pada Pasal 1 C.

Prado, G. C. 2000. Starring With Foucault: anintroduction to genealogy. Westivew Press.

Presiden. 1999. Kerpres Nomer 29 Tahun 1999 Pasal $1 b$.

UU RI. 1947. Undang-Undang No. 33 Tahun 1947 Pasal 6 Tentang Buruh, Kecelakaan. Undang-Undang Kecelakaan.

UU RI. 1969. Undang-Undang No. 14 Tahun 1969 Tentang Tenaga Kerja Pasal 1.

UU RI. 1997. Undang-Undang No. 25 Tahun 1997 Tentang Ketenagakerjaan.

UU RI. 2000. Undang-Undang No 21 Tahun 2000 Tentang Serikat Buruh Serikat Pekerja.

UU RI. 2004. Undang-Undang No. 39 Tahun 2004 Tentang Penempatan dan Perlindungan Tenaga Kerja Indonesia di Luar Negeri. 